\title{
The importance of environmental and sustainability education in tourism based on the opinion of students at Budapest Business School
}

\section{Abstract}

In this study, the relationship between sustainable universities and environmental education is analysed from the aspect of tourism as seen by students. The research showed why green universities are important and what green applications were implemented at Budapest Business School. 1050 people participated in thesurvey examining the connections between green universities and environmentally conscious modes of living. All respondents were students of Budapest Business School and data was collected from the 18-22 years age group.

We started out with the assumption that the students at Budapest Business School are aiming at becoming responsible citizens of tertiary education and as they will be senior and junior level managers they could exert great influence on the green development of the economy in the future.

The authors consider it a success, that a green university will lead the ranking of universities which will become the winners of the 4 th industrial revolution. Mastering sustainable subjects improve comprehensive and cohesive thinking. Energy and cost reduction is not the only goal in higher education; integrating sustainable subjects into courses and putting them into practice are also important. The courses in sustainable tourism significantly re-evaluate students' commitment to sustainable development.

\footnotetext{
1 Budapest Business University; e-mail: bagdadi1212@gmail.com

2 Budapest Business University; e-mail: remenyik.bulcsu@uni-bge.hu DOI: http://dx.doi.org/10.31570/Prosp 2021_1_1
} 
The research emphasizes the importance of the sustainabilitys issue with regards to educational institutions and green universities, and it inspires us to take some action at the same time.

Keywords: green universities, Budapest Business School, environmental education, green economics, sustainable development, sustainable tourism

\section{Introduction}

The authors assume that the training of these types of students could mostly be undertaken by the science of tourism, so it would be expedient to prescribe at least one sustainable, responsible tourism course for undergraduates within the economy training curriculum of the university. As part of the course having a special focus on environmentally conscious behaviour, a new type of student characterized by responsible behaviour will be formed, one who acts pro-actively for the environment, does not leave waste about, refrains from causing damage or noisy behaviour. Responsible students become more environmentally conscious, sensibly reduce the use of resources, conserve natural treasures, prefer healthier nourishment, and sustainable means of transport when going to work. In this survey when students were asked about their criteria for selecting a tertiary level educational establishment for their studies, we found that the brand proved to be the decisive factor. Thus the motto "Centre for training for green university citizens" may be instrumental in shaping a responsible image, a worthy brand.

Sustainability is getting more and more topical in everyday life so school leavers will also become more receptive to these changes. Through their research the authors showed why green universities are important and what green applications were implemented in Budapest Business School.

A sustainable university is define as "an educational institution which trains global citizens for sustainable development, offers relevant insight into urgent social challenges, reduces environmental and social footprints of the operation of the campus, authorizes undergraduates and employees for action and makes sustainability a central priority" (Besenyei 2019). Scanning the list of green universities the first name is the University of Szeged at the eminent 74th place, ranked also among the bests in all international and domestic lists. 
Nine Hungarian institutions have made the GreenMetric list published in 2019 and their domestic ranking is as follows (GreenMetric, 2020):

1st place: University of Szeged - 74th place, 7375 points, 2nd place: University of Pécs - 100th place, 7025 points, 3rd place: Eötvös Loránd University - 244th place, 5825 points, 4th place: University of Debrecen - 354th place, 4750 points, 5th place: Budapest Bussines School - 491th place, 4425 points, 6th place: University of Miskolc - 498th place, 4075 points, 7th place: Budapest Corvinus University - 525th place, 3950 points, 8th place: Saint Stephen University - 532nd place, 3900 points, 9th place: Óbuda University - 595th place, 3375 points.

As a green university, the case of the University of Szeged was analyzed (Málovics et al. 2016). The authors agreed that sustainability should extend to the research, educational, operational, and strategic proceduress of the campus and the university and the social connections of the university. Budapest Business School is striving to upgrade its position in various databases, so seven areas of university sustainability were proposed to be accepted as relevant (Lozano 2016):

- The institutional frameworks, such as the strategies, vision, sustainability agreements signed or the mission statement.

- A similar factor is the sustainability of the campus including the purchase of foodstuffs; transport, traffic, energy consumption and efficiency, greenhouse gas emission, treatment of waste and sewage and accessibility.

- Sustainability should be included as a component of education either within the framework of courses or the training programs.

- The fourth area brings into focus the establishment of sustainabilty research centres, implementing holistic thinking and the application of new technologies.

- Another important aspect is the connections with local communities by means of student exchange programs, joint training sessions and joint research projects.

- Live experiences of sustainability in the campus with sustainability working groups and practices and sensitization programs in cooperation with students and the teaching staff.

- And to conclude with the last area of the sustainability audit, communication, reports and rankings. 
The Tbilisi Declaration (1997) states, that environmental education is a kind of process, through which such a generation is growing up worldwide, which knows its wider environment, cares about it and its problems. They possess all the knowledge, skills, attitudes, motivations and commitments so that both groups and individuals can work on the prevention and solution of problems (Svanstrom-Lozano-GarciaOtt 2008). Environmental education is there to provide everyone a method to improve their own quality of life and resolve environmental issues. The application of these methods would help further improvements of opportunities, just as the regeneration and prevention of the damages in nature. Environmental education is a holistic approach because it has an impact on the potential person's worldview, lifestyle and even on his or her culture. In the course of environmental education, the person acquires a kind of knowledge, set of values and information that has a motivational force. This motivational force ensures the effective and careful exploitation and usage of natural resources, and intensifies social responsibility towards environmental protection (Kiss et al. 2006).

The key to humanity's survival is whether and how the processes of the current economics keep continuing. What is the responsibility of future generationsconcerning the planet and the fate of fellow human beings. Though some authors (Barth et al. 2007) emphasize the interdisciplinary nature of sustainable education, actions are lacking on the part of economics. Sustainable development is the most burning questions of our lifetime, and for changes to be made, education should also deal with these problems (Fassbinder et al. 2014). Obviously, staying within the university frameworks and approaching from the side of natural sciences, sustainable education is undertaken mostly by the subject of biology (Sima et al. 2019). However, in the field of economics, tourism research could form the base of future education.

With the course of this research, we would like to exemplify, that not even on university level would the implementation of one or two sustainable investments be enough. It is highly important to introduce environmentally conscious, sustainable thinking to education and also the continuous controll of improvements. The initiatives should not be only fulfilled on paper (Bekessy et al. 2007). Svanstrom developed a system of indicators to measure similarities and differences among the institutions of higher education (Svanstrom et al. 2008). To complete the 4C model (Community, Curriculum, Culture, Campus), of the implementation of the sustainable university a fifth component - Control - should be included as well (Johns et al. 2010). Based on the above, it may not be surprising, that more and more attention is given worldwide to the teaching of sustainability. The international community is devoting a whole decade to achieve 
the goal of having all the levels and types of education permeated by the principles of sustainability (Unesco, 2014).

It's essential, that the knowledge in connection with sustainable development, the competencies, and advanced behaviour would appear in the program of certain subjects. Exceeding the limits of the non-environmental sciences (mainly biology) would be assisted by the pedagogical goals of sustainable development to be integrated into all the fields of education. On the other hand, the cooperation of university professors and instructors, who teach various subjects, should be encouraged to help the education for sustainable development (Svanstrom et al. 2008). This chance of cooperation would provide for, beyond the methodological reform of each subject, the improvement of certain teacher competencies. At the same time, this workshop requires the creation of proper frames. Principally, it probably can be shaped through the example of projects which impact the successful and efficient local society. However, this requires good practices to be presented as widely as possible.

\section{Methodology}

During the writing of the article, the authors conducted a primary and secondary analysis, where the authors used regional science research methods (regional science examines the persistent processes that shape territorial inequalities in society). The authors began with the basic thesis, that higher education will become the big winner of the 4th industrial revolution and green universities will lead the university rankings. The lists of higher education rankings QS (QS Rankings, 2020), Times, ARWU (ARWU, 2020), HVG were compared, whereby the authors concluded that the research hypothesis is proved to be valid (both internationally and in Hungary). Through the analysis of the Greenmetric and AASHE STARS lists (AASHE STARS Dashboard, 2020), the authors assumed that the integration of sustainable subjects into education is becoming more prevalent/dominant in Hungary as well. An examination of the curricular networks of Hungarian universities on the Greenmetric list has, however, refuted this hypothesis, courses on sustainability (in Bachelor and Master courses) are among the elective ones only. Hungarian universities understand cost reduction (energy and water) under the definition of green university rather than the expansion in the number of sustainable courses. However, this approach also seems to lead to a significant improvement in rankings, and the authors have tried to prove this through data analysis in making one of Budapest Business School's faculties sustainable, and as a result the university jumped ahead 135 places on the Greenmetric list. (GreenMetric Rankings, Overall 
Rankings, 2020) In the following section the autors attempt to find out why it would be necessary to integrate sustainable courses into the programmes if a university can still achieve success without them. The literature review has shown that learning about sustainability will generate a complex mentality/thinking (Wheeler-Bijur 2013) by developing competencies (Hipkins et al. 2014) that help the students to easily understand general contexts and think systematicly. The authors can safely say that the respondents agreed with the statements of the literature.

The Decade of the Education of Sustainable Development as announced by the United Nations (www.accor/planet21.com) was successful. Sustainable development is acquiring more efficient role in education (Hopwoo et al. 2005; Sterling 2016) and $92 \%$ of respondents would like to learn more about the topic. The analysis of the results sheds light on the oblstacles that obstruct the attempts to promote sustainability at the University (Bellou et al. 2017). However, the authors revealed through this survey, that environmental education will not be implemented in practice as the research claimed in 2001 (Havas 2001). This research analysis also highlighted the fact that the students from the Faculty of Commerce Hospitality and Tourism show more interest in the topic than scholars of any faculty. The authors used cluster analysis for the evaluation of the survey where the authors placed the students from FCHT in one group. They considered it important to develop a responsible mentality. Most of them referred to the negative effects of overtourism in Budapest. In the topic of environmental education, they mentioned coexistence with nature or reducing our ecological footprint as a major challenge referring to the example of the fast destruction of natural attractions. During the evaluation of the questionnaire, the authors were also curious about students' satisfaction with the courses. Many negative experiences were reported and they found it strange that the sustainable courses are only among the elective ones. The respondents came from the young and middle age groups. In the completed questionnaire, $70 \%$ of the respondents were female and $30 \%$ male.

The task-related to green universities in environmental education constitutes the training of environment-conscious university citizens. In the questionnaire, the authors sought to find answers to the questions why students find the education of such citizens important and to what extent are those specialized in tourism more environment-conscious as compared to those of other fields. The survey has shown that an environment-conscious mode of living offers an antidote to the secluded lifestyle generations $\mathrm{Y}$ and $\mathrm{Z}$ have been pioneering while growing up. Those who live a life close to nature are physically more active, are more aware of proper nourishment, are more creative and sensitive in the social spheres, and show more empathy to their partners. 
Children become more active and several health problems like obesity, attention deficit, or depression can be prevented. Environment-conscious education may contribute to making the acquisition and application of scientific, technological, engineering, and mathematical knowledge more attractive. A special kind of structured knowledge is formed which can be exploited in the future. The processes of defining, analyzing, interpreting problems, drawing conclusions, and working out solutions are improved. It is instrumental both in co-operation-based learning with peers and in critical thinking. Chances for rich, practical, real-life, and genuine learning are provided in the curriculum. More attention and inspiration are perceived by them than in the world of traditional pedagogy.

The question on selective waste collection showed that $50 \%$ of the respondents protect the environment by selective waste collection. This was a rather popular answer and usually, their residence encouraged the behaviour by placing selective waste collection bins around. The other thing that was mentioned by a large proportion of the respondent was to avoid littering in public places thereby contributing to cleanliness. One-third of the respondents regularly take part in rubbish collection campaigns. Almost one-third of the respondents consider paying attention to the use of resources an appropriate means of conservation of the environment, however, only a small proportion of them pay attention to their use of paper. $30 \%$ of the respondents carefully choose the most environment-friendly means of transport: by riding their bikes, walking or, if necessary, taking public transportation. 35\% selectively collect batteries too and avoid using chemicals harmful to the environment. $10 \%$ of them are conscious of packaging and take along their own bags thus refusing the use of nylon ones. However, of 1050 people asked there was only one who answered that he was trying to become environment-conscious by studying it in his free time and is already interested in the topic. With the presentation of the Zalaegerszeg project, we would like to pay tribute to the work of Katalin Solt.

\section{Results}

A great majority of the respondents believe the issue of nature conservation is important, three-fourth of them would be ready to make contributions, if they could. They also mentioned that the education of the youth to promote an environmental-conscious behavior is an issue of primary importance. In the next group of questions, the authors requested answers as to what extent are the students mindful of nature during their travels. A sizeable proportion of people are concerned with nature conservation 
during their holidays too, their concern is not confined to their residence only. When asked what forms does this interest take during the holidays the answers were about the same as before: a selective collection of waste, avoiding litter to be left about and mindful usage of water and energy. It can be seen that the behaviour of respondents does not show much difference from the day-to-day routine of environmental consciousness. A few respondents mentioned that when they are traveling and staying in hotels they do not require daily cleaning and towel replacement. A small fraction of respondents gather information about local environmental regulations and strive to observe them. Two people answered that they do not just avoid leaving waste about but also collect other people's litter when they are on holiday. There was one person who prefers to make choices in harmony with environment-conscious values such as staying at energy-friendly accommodation during holidays. All respondents agreed that even if they do not have too many chances they invariably try to keep the cleanliness of their place of destination. The majority of respondents also agree that environmental consciousness plays a major role during their travels, however, opinions differ about the extent of that role.

The authors also wanted to know whether they prefered to stay at hotels participating in green programs. To this question the majority of the answers were affirmative. From the negative answers, it was obvious that the respondents believe: green hotels are more expensive than ordinary ones. The next question enquired, whether a destination where the respondents were more likely to return to a destination where they found the issue of the conservation of the environment a high priority. Only one-third of the respondents said yes, the rest of them may turn up again but not for that particular reason.

A destination offering rest in a green environment is an attractive characteristic and respondents would gladly recommend it to friends and acquaintances. Analyzing the environment consciousness of respondents the following conclusion was drawn: those who pay attention to the conservation of the environment in their everyday life are more open to green events as well. The responses here are promising. $46 \%$ of the respondents claimed they are environmentally conscious and only $11 \%$ gave a negative reply. A real success story would follow if the hesitant group representing $43 \%$ could be turned in the right direction.

We also surveyed the kinds of practical environment conservation steps that could be introduced at events and visitors would not find them disagreeable. A significantly smaller group of respondents would pay attention to invitations to purchasing large quantities of products, opting for environment-friendly transport, or buying local products. 
A very positive result was produced by the respondents to the question of to what extent they think environmental conservation should be considered at various events since everyone (100\%) found it important though at various levels. Half of the respondents (51\%) think it is important, $43 \%$ believe it is very important that environmental conservation plays a role at university events. The remaining $6 \%$ ticked off the answer of moderately important. The authors believe that such a high rate of support for environmental-friendly measures shall, by all means, make the issue more popular in professional circles.

Respondents were asked to put themselves in the position of an event organizer and if they were responsible for choosing venues, to what extent would they consider the environmental conservation features that the various sites may offer important. $74 \%$ of the respondents ticked off the answer that though these features would be taken into account the decision shall not be made on the basis of these points but e.g. based on the price and some other factors. $21 \%$ of the respondents would list environment conservation measures among the points of primary importance.

In one of the last questions, the authors asked participants to mark what they think about the standards, organization, and popularity of green events. The majority of laymen similarly to professional people believe that the organization of green events is more complex and expensive than those of the traditional ones, however, a great majority maintains that the events are of a higher quality. Almost half of the respondents claim that green events are less popular.

In conclusion, the authors asked students' opinion about a sustainable Alma Mater training restaurant the answers to which can be seen as follows (https://fenntarthatovendeglatas.hu/):

- The re-glass system is known by $68 \%$ of the students and a total of $64 \%$ think it is a very good idea. Not too many, only $21 \%$ of the respondents have already met with compostable plates and cutlery, however, a total of $61 \%$ claim their use is a great idea.

- 75\% of respondents have not yet come across presents made of re-used materials, however, a total of $52 \%$ of the respondents think it is an excellent idea.

- Only 33\% of the respondents have already seen creative corners, where people can construct new objects made of reusable materials (e. g. inner tubes of tires, plain cotton clothes) and only a total of $45 \%$ think of this option as a very good idea. 
- $55 \%$ of the respondents have already met with movement-sensory water taps and a total of $58 \%$ believe it is a very good idea.

- Use or purchasing opportunities of bio, eco and fair-trade products raised the interest of $49 \%$ of the respondents who found those really good, however, a $21 \%$ group showed indifference to such changes.

- The conclusion drawn as a summary of the evaluation of the questionnaire is that students specialized in tourism are $20 \%$ more environmentally conscious than those specialized in commerce.

\section{Findings}

In relation to eco-efficiency, the respondents emphasized the importance of green purchases, of which they put energy-saving bulbs, heat insulation systems, and renewable sources of energy to the top of their list of priorities.

Figure 1: Ratio of environment conservation alternatives based on the customs of respondants

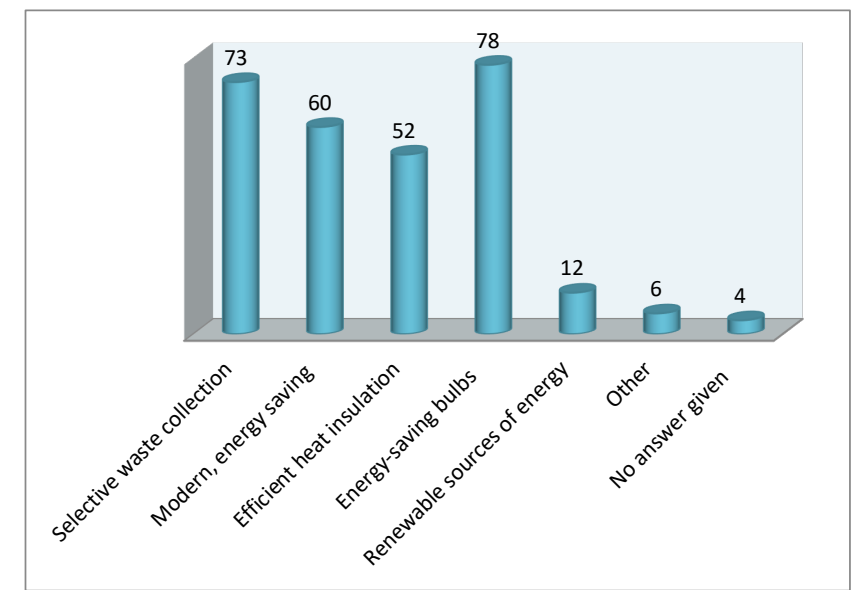

Source: Own work

In connection with green purchases, the Planet21 program of Accor Hotel Group was the most commonly known by students on the basis of which they emphasized the importance of the purchase of eco-friendly products (in 2015) 85\% of Accor Hotels made use of eco-friendly products including environmentally friendly cleaning agents (51\%) distemper (23\%) and flooring (10\%) (www.accor/planet21.com). By the annual operation of the university, a sum total of $216.290 \mathrm{~kg}$ carbon dioxide emission enters 
the air (www.bge.hu), approximately half of which originats from electric equipment (www.bge.hu). In order to counterbalance also that students again made mention of the "Plant for the Planet" program learned in Planet21. In order to reduce the energy footprint of the university respondents attached importance also to the use of solar collectors. The energetic renewal of the Faculty of Commerce of Budapest Business School was launched in 2011. In the framework of the Environment and Energy Operative Program (KEOP) using an EU subsidy of approximately HUF 143 billion the Green Campus Zalaegerszeg sample project (KEOP-6.2.0/A/11-2011-0005) was realized between 01.02.2012. and 20.01. 2014. (https://uni-bge.hu/GKZ/Projekt/Zold-Kampusz). It was an important part of the decision that the investment was co-subsidized in the framework of the New Széchenyi Plan. 50\% of the investment costs had to be covered by own sources and for the other $50 \%$, a non-refundable subsidy was granted.

The exact object of the investment included 8 pcs solar collectors with a total area of 20.5 square metres and two storage containers of 120 litres each, a $160 \mathrm{~kW}$ capacity pellet boiler and a 5.000 litres volume buffer boiler pertaining to it. Investment costs worked out as follows:

Construction of solar collector system:

Construction of biomass based heating:

Total investment costs:
HUF 5,076,860

HUF $26,173,700$

HUF $31,558,560$

The annual capacity of the solar collectors is $16,350 \mathrm{kWh}$ which is sufficient to produce 350,000 litres of hot water supply. The annual energy requirement for the production of hot water supply based on previous experience in the building amounts to 25,550 kWh, which means that the Faculty uses approximately 547,000 litres hot water annually. From the ratio of the annual quantity of energy produced by solar collectors and the annual amount of energy required for the production of hot water supply it can easily be figured out that the solar collectors are capable of producing $64 \%$ of the required hot water supply $(16,350 / 25,550=0.64)$. Based on the statistics of previous years the annual electric energy consumption of the building amounts to $149,254 \mathrm{kWh}$, if that is taken as a basis, the solar collectors can produce almost $11 \%$ of the annual electric energy consumption $(16,350 / 149,254=0.109)$.

The pellet boiler was expressly selected to enable it to provide for the complete heating of the Faculty. Thus the heating energy is exclusively produced by renewable sources, the pellet boiler can produce $100 \%$ of the energy required for heating. Owing to that the Faculty can save the complete heating charges. However, the autors should 
not forget the material requirements of the pellet boiler. According to the executive report the annual energy required for the heating of the building was 740,000 MJ. This figure divided by the heating value of the pellet $(18 \mathrm{MJ} / \mathrm{kg})$ shows that the annual pellet requirement amounts to approximately $41,111 \mathrm{~kg}$ pellet $(740,000 \mathrm{MJ} / 18 \mathrm{MJ} / \mathrm{kg}=$ $41,111 \mathrm{~kg}$ ). Now that multiplied by the price of the pellet, which is HUF net $40 / \mathrm{kg}$, means the annual material requirement of the boiler is HUF 1,644,444.

Savings at the Faculty of Commerce resulting from the use of renewable resources of energy are as follows:

- In the case of solar collectors the sum total of savings can be calculated by multiplying the annual electric energy consumption with the unit price of electric energy (HUF 35,125/kWh) thus the charge of electric energy would be HUF $149,254 \times 35,125=5,242,547$ if no solar collectors were used. However, the solar collector annually produces $16,350 \mathrm{kWh}$ "free energy". If that is subtracted from the annual consumption, then the sum obtained is also multiplied by the unit price and finally the diference between the two results are taken. Thus we can see that the annual savings of the Faculty amount to HUF 574,364. [(149,254 $16,350) \times 35,125=4,668,183 ; 5,242,547-4,668,183=574,364]$.

- In the case of heating the total base fee, which so far was HUF 1,232,961 annually and the heating costs can be saved for the Faculty. Adding the two figures up we find that HUF 3,790,401 was spent on heating. Subtracting the pellet costs from that figure shows that the Faculty saves HUF 2,145,957/year.

Figure 2: Energy costs before and after the investment (blue: before the investment, orange: after investments)

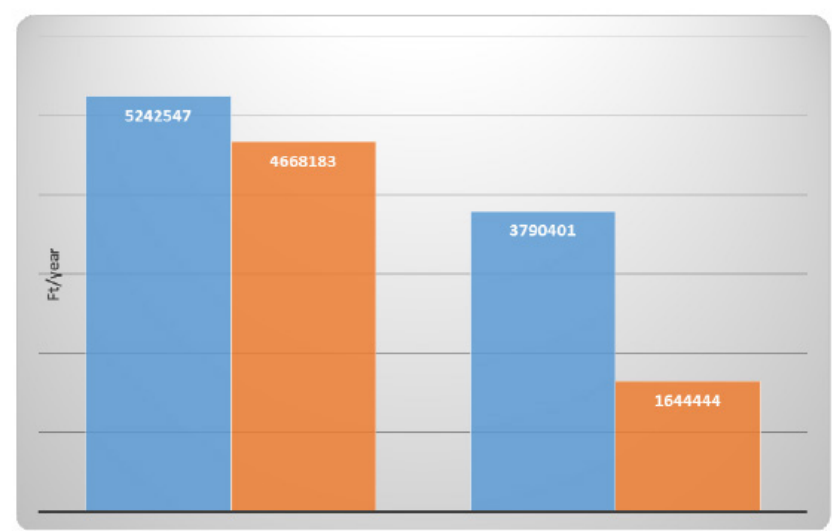

Source: Own work 
From the above chart we can easily deduce that in the case of heating a significant reduction of costs has been attained. Electric energy costs have been reduced by $11 \%$, while those of heating by almost $57 \%$. If the two are combined than the total reduction of energy costs in the building amounts to more than $30 \%$.

Calculating with static return the rate of return can be calculated as follows: investment costs/annual savings $=$ rate of return in years. Calculated on that basis the accurate rate of return can be seen in the table below.

Table 1: Development of return on investments

\begin{tabular}{c|c|c} 
& Solar collector & Pellet boiler \\
\hline Investment (HUF) & 5.076 .860 & 26.173 .700 \\
\hline Savings (HUF/year) & 574.364 & 2.145 .957 \\
\hline Static return (year) & 8,84 & 12,19 \\
\hline
\end{tabular}

Source: Own work

Thus the return of the construction of the solar collector system and that of the biomass heating system are 8 years and 10 months and 12 years and 3 months respectively. If we take the fact into consideration that $50 \%$ of the investment costs were covered by subsidies than the static return index becomes even more favourable cutting previous figures by half.

The senior management of the university is completely satisfied with both the performance of the equipment and the rate of reduction of the costs of energy consumption. No unexpected problems or costs occured either during the construction works or in the operational phase. No extra costs as a result of technological installations occured at other areas of the Faculty either, the equipment do not require special maintenance and there is no need for extra workforce either. Before the investment the energetic qualification index of the building was better $(B)$ than the requirement and after the investment it has become highly energy-saving $(\mathrm{A}+)$.

\section{Discussion}

As early as 1948 during the session of the Education Committee of the IUCN a declaration of intent was made calling for the requirement of education aiming at the conservation of the environment (Kosáros 2007). The first definition of environmental 
education itself and its first publication in the press can be dated "only" to 1969. It was the year when William B. Strapp. who later became the first director responsible for environmental education at UNESCO in The Journal of Environmental Education published his definition and his idea has been used as the bases of prevalent definitions ever since. The IUCN definition adopted in 1970 in addition to the themes of seeking knowledge, becoming aware of problems and making people motivated declare the need for restatement of knowledge and concepts related to environmental education thereby calling for the specification of a necessary framework and in association with that also makes mention of the scope of responsibilities of the decision makers. The basic principles like precaution, knowledge, attitudes, skills and participation then laid down have still retained their significance. That was the initiative of work and as an outcome UNESCO and UNEP jointly brought about their declarations enacting a legal background of environmental education during some years in the 1970s. In 1972 the Stockholm Declaration drafted only 33 basic principles and proposals in order to expand and save the human environment since it was time when global environmental problems effecting the whole world became widely known (DUNCHE, 2020).

However, the Belgrade Charta (1975) taking into consideration also former basic principles identified objectives and tasks too regarding the environmental education program and it was at the same time the birthplace of IEEP ${ }^{3}$, the International Environmental Education Program of UNESCO and the UN ${ }^{4}$. The Tbilisi Declaration, the next milestone, which at the same time can be considered the basic document of environmental education, was made with the aid of the two former antecedents in 1977. Special bibliographies show due regard for it as the true foundation-stone of environmental education drafted in the National Environmental Education Strategy as follows: "Environmental education is a process, in which a global generation is brought up who are also aware of their wider environment as well which they care for and its problems they concern themselves about. They are equipped with knowledge, skills, attitudes, motivation and dedication so that they could work both as indivduals and in communities for the solution of existing and the prevention of subsequent problems" (Kiss-Zsiros 2006).

Since 2010 the development of green universities is enhanced as there is governmental commitment to the dissemination of the idea of environmental education. Figure No. 3 illustrates the rise of sum total spent on allocations for instructions important

3 International Environmental Education Program.

4 United Nations Organization. 
from the point of view of environmental education. Analysing the data of the Central Statistical Office it can be stated that since the accession of Hungary to the European Union the $2 / 3$ rd of environmental conservation costs of the national economy account for water supply, sewage treatment waste management, utilization of waste, the sum total of costs in 2018 reached HUF 260 billion (www.ksh.hu/tajekoztatasi). At the time of the EU accession Hungary was in great arrears as compared to the European regulations and we are still paying the costs of closing up in this field. A considerable amount of funds spent on tourism has been redistributed to the headwords of landscape and nature conservation and environmental research.

Figure 3: Changes in the sum total in the expenditure spent on education in the headword landscape and nature conservation

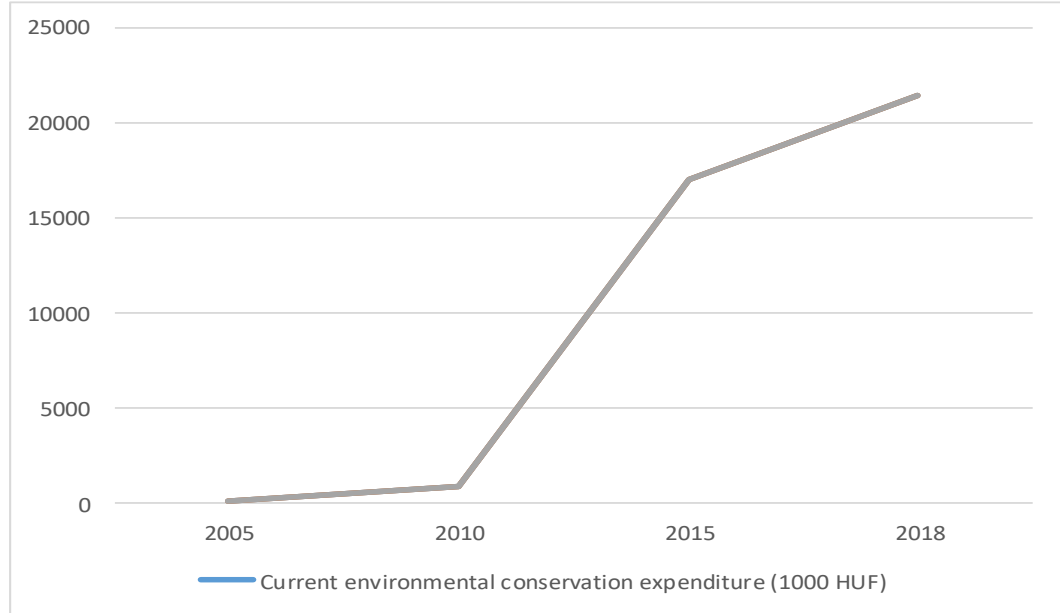

Source: Own work

Based on Figure No. 3 it can be stated that significant tasks are assigned by the government to the tourism industry in the training programs of environmental education.

\section{Conclusion}

The limitations of the research were that there are only a few Hungarian universities on the green metric list and research was focused on applications and respondents who were studying at Budapest Business School. Industrial revolutions are linked to education (Blinder 2006) currently referred to as the 5th economic sector, presented as a power due to being a disseminator of knowledge (Gabbard 2007). Only those who 
think systemically and have a complex vision can be the winners of new challenges (Schwab 2020). All this is important because knowledge and the university are already appearing as "brands" (Pearman 2013). United Nations Education for Sustainable Development (ESD) wants to empower people to change their way of thinking in order to strive for a sustainable future (Erdogan 2009). This is clearly related to the sustainability transition of higher education (Rieckmann 2012).

At the outset, the hypothesis was that tourism could enhance environmental thinking within the framework of economic education. Generally, sustainability topics (e. g. environmental protection, waste management, and sustainable development) are largely addressed and, to some extent, applied in faculties dealing with earth sciences (e. g. geography, ecology) and technical sciences (e. g. environmental engineering) (Sima et al. 2019). Topical sessions throughout could be integrated into the curricula with a special approach to the various subjects so that the question of sustainability is dealt with in a conscious manner. Students' opinions underlined that universities also set examples and show trends for development towards a sustainable environment, society, and economy.

Respondents generally agreed that the integration of sustainability in education is one of the major factors of development. Undergraduates shall be aware of the practical and theoretical background of the topic. Young people are floded day and night with the environmental, economical, political, and social problems presented by the social media should start to take action. However, this requires them to be up to the task. It has become the social responsibility of education to train graduates, who possess these skills. This is the time to show and to teach generations of the future how to live with a difference.

Is getting in a car the only way to the university? And how about riding a bike, walking or using public transport? People shall be taught what damage they may cause by littering or prevent by selective waste-disposal. Buzz words like recycling, renew, reuse have vast practical and theoretical potential. To conclude with a painful lesson: the BBS is lagging far behind the University of Szeged. To our greatest regret the survey about the environment-conscious modes of living of university citizens produced results far below our expectations. Though the results of tourism students were $20 \%$ better than those of other specializations in a European Union level comparison failure to achieve can still be called considerable. In addition to raising energy efficiency, selective waste disposal and reuse of materials the attitude of sustainability does not really prevail at the university. Plants and green areas are scarce, there are no compost piles, the equipment the people use are of high energy consumption, the structure and the material 
quality of the university building do not comply with any environment-friendly aspect. However, there are multi-functional spaces we can be proud of, a restaurant underneath the university and an auditorium well-equipped with state-of-the-art ICT technology which can serve as a venue for events not directly related to the university. The institutes of higher education could successfully use relational strategies to promote sustainability across multiple campus groups and departments by recruiting campus ambassadors, collectively defining sustainability, and sharing public progress reports (Carpenter 2016).

\section{References}

AASHE STARS Dashboard (2020). https://reports.aashe.org/institutions/data-displays/dashboard

ARWU 2020. http://www.shanghairanking.com/ARWU-Metho dology-2018.html\#2

Altbach, P. G. - Reisberg, L. - Rumbley, L. E. (2009). Trends in Global Higher Education: Tracking an Academic Revolution. Paris. UNESCO.

Barth, M. - Godemann, M. - Rickmann, J. - Stoltenberg, U. (2007). Developing key competencies in sustainable develeopment in higher education. International Journal of Sustainability in Higher Education, 8(4), 416-430. https://doi. org/10.1108/14676370710823582

Bekessy, S. A. - Samson, K. - Clarkson, R. E. (2007). The Failure on Non-binding Declarations of achive university-sustainability. International Journal of Sustainability in Higher Education, 8(3), 301-316. https://doi.org/10.1108/14676370710817165

Bellou, C. - Petreniti, V. - Skanavis, C. (2017). Greening the campus intentions: A study of the University of the Aegean non-academic staff. International Journal of Sustainability in Higher Education, 18(4), 520-532. https://doi.org/10.1108/ ijshe-05-2015-0102

Besenyei M. (2019). Egyetemi fenntarthatósági kezdeményezések összehasonlító elemzése. Budapest: Budapesti Corvinus Egyetem.

Blinder, A. S. (2006). Offshoring: The next industrial revolution? Foreign Affairs, 23(1), 113-128. https://doi.org/10.2307/20031915 
Carpenter, S. - Takahashi, B. - Lertpratchya, A. P. - Cunningham, C. (2016). Greening the campus: A theoretical extension of the dialogic communication approach. International Journal of Sustainability in Higher Education, 17(4), 520-539. https:// doi.org/10.1108/ijshe-02-2015-0036

DUNCHE 1972. Declaration of the United Nations Conference on the Human Environment.

Erdogan, M. (2009). Evaluation of a Course: "Education and Awareness for Sustain ability". International Journal of Environmental \& Science Education, 4(2), 133-146.

Fassbinder, S. D. - Nocella, A. J. - Kahn, R. (2014). Greening the Academy. Rotterdam.

Gabbard, D. (2007). Knowledge and Power in the Global Economy: The Effects of School Reform in a Neoliberal/Neoconservative Age. Oxford: Routledge.

GreenMetric Criteria, Criteria \& Indicators 2020. http://greenmetric.ui.ac.id/criterianindicator/

GreenMetric Rankings, Overall Rankings 2020. http://greenmetric.ui.ac.id/overallranking-2018/

Havas P. (2001). A fenntarthatóság pedagógiai elemei. Budapest: Új Pedagógiai Szemle. Hipkins, R. - Bolstad, R. - Boyd, S. - McDowall, S. (2014). Competencies for the Future. Wellington: NZCER Press.

Hopwoo, B. - Mellor, M. - O’Brien, G. (2005). Sustainable development: Mapping different approaches. Sustainable development, 13(1), 38-52. https://doi.org/10.1002/ $\underline{\text { sd. } 244}$

Johns, P. - Selby, D. - Sterling, S. S. (2010). Sustainabiltity Educations. London-New York: Earthscan Publishing.

Kiss F. - Zsiros A. (2006). A környezeti neveléstől a globális nevelésig [on-line]. Oktatási segédanyag: http://www.nyf.hu/ttik/sites/www.nyf.hu.ttik/files/doc/kornyezeti neveles.pdf

Kosáros A. (2007). A fenntarthatóság szerepe a környezeti nevelésben. Doktori értekezés, Debreceni Egyetem Természettudományi Doktori Tanács Környezettudományi Doktori Iskola, Debrecen: http://ganymedes.lib.unideb.hu:8080/dea/bitstream/2437/78560/5/

Lozano, R. (2016). A holistic perspective on corporate sustainability drivers. Corporate Social Responsibility and Environmental Management, 22(1), 32-44. https://doi. org/10.1002/csr.1325 
Málovics G. - Juhász J. - Hajdu K. - Gyarmati L. (2016.) Az egyetemek környezeti fenntarthatóságának megközelítései a Szegedi Tudományegyetem megközelítésén keresztül. Vezetéstudomány, 47(6), 16-29. https://doi.org/10.14267/veztud.2016.06.02

Pearman, I. (2013). Times higher education. https://www.timeshighereducation.com/ world-university-rankings/2013/reputation-ranking/analysis/universities-arebrands

Rieckmann, M. (2012). Future-oriented higher education: Which key competencies should be fostered through university teaching and learning? Futures, 44(2), 127135. https://doi.org/10.1016/j. futures.2011.09.005

Schwab, K. (2020). The fourth industrial revolution: What it means, how to respond. https://www.weforum.org/agenda/2016/01/the-fourth-industrial-revolution-whatit-means-and-how-to-respond/

Sima, M. - Grigorescu, I. - Balteanu, D. (2019). An overview of campus greening initiatives at universities in Romania. International Journal of Sustainability in Higher Education, 20(3), 410-422. https://doi.org/10.1108/ijshe-01-2019-0036

Sterling, S. (2016). A commentary on education and sustainable development Goals. Journal of Education for Sustainable Development, 10(2), 208-213. https://doi. org/10.1177/0973408216661886

Svanstrom, M. - Lozano-Garcia, F. J. - Ott, D. (2008). Learning outcomes for sustainable development in higher education. International Journal of Sustainability in Higher Education, 9(3), 339-351. https://doi.org/10.1108/14676370810885925

THE 2018. World University Rankings, https://www.timeshighereducation.com/ world-university-rankings/methodology-world-university-rankings-2019

QS Rankings 2020. https://www.topuniversities.com/qs-world-university-rankings/ methodology

Wheeler, K. A. - Bijur, A. P. (2013). Education for a Sustainable Future: A Paradigm of Hope for the 21st Century. Berlin: Axel-Springer.

https://uni-bge.hu/GKZ/Projekt/Zold-Kampusz

https://fenntarthatovendeglatas.hu/

www.accor/planet21.com

www.ksh.hu/tajekoztatasi adatbazis/kornyezetvedelem

https://sustainabledevelopment.un.org/index.php?page=view\&type $=400 \& n r=1682 \&$ $\underline{\text { menu }=35}$ 